\title{
TPI1 Gene
}

National Cancer Institute

\section{Source}

National Cancer Institute. TPI1 Gene. NCI Thesaurus. Code C105557.

This gene plays a role in glycolysis and gluconeogenesis. 